\title{
Experiments in Physics Learning in the COVID-19 Era: Systematic Literature Review
}

\author{
Arif Rahman Aththibby ${ }^{1,2^{*}}$ Heru Kuswanto ${ }^{1,}$ Mundilarto $^{1}$ \\ ${ }^{1}$ Graduate School, Universitas Negeri Yogyakarta \\ ${ }^{2}$ Physics Education Program, Universitas Muhammadiyah Metro \\ *Corresponding author. Email: aththibby.2017@student.uny.ac.id
}

\begin{abstract}
The COVID-19 pandemic has influenced global conditions globally, including in the world of education in Indonesia. The implication of the COVID-19 pandemic is learning that initially focused on face-to-face shifting to distance learning / online learning. This condition is also a challenge in learning physics. This is inseparable from learning physics which requires experimental activities therein. This article will review the potential use of various platforms in solving laboratory-based physics learning problems in the COVID-19 pandemic era. To produce a comprehensive analysis of this potential picture, a systematic literature review is conducted. The analysis shows that various platforms are very potential in solving physics learning problems that require experiments for physics teachers in the pandemic era COVID-2019.
\end{abstract}

Keywords: Experiments, Physics Learning, COVID-19 era.

\section{FIRST LEVEL HEADING}

The aim of physics education is to develop student skills in the inquiry which are supported by scientific knowledge and scientific approaches [1], [2]. Basic laws in physics are expressed in mathematical language tools that provide a bridge between theory and experiment [3]. Physics will be difficult to understand if only learned through imagination. It is difficult to imagine learning to do science or learning about science without conducting laboratory experiments or fieldwork [4]. Therefore, laboratory and experimental activities which are one of the characteristics in learning physics can be an alternative solution in overcoming this gap. Practical activities can be done if the learning media is used appropriately.

One problem that is often encountered is related to equipment limitations, several other issues also need to be considered related to the current state of laboratory learning. First, lecture activities sometimes work activities that are not in line with lecture activities. Second, there is no interaction between class lectures and laboratories. Finally, there are big differences in teaching abilities and the performance of different practicum assistants. Therefore, the current situation is contradictory and does not support approaches that are able to foster creativity, interest, increase understanding, and positive attitudes [5].

The Coronavirus 2019 pandemic (COVID-19) has created significant challenges for the education community globally [6]. The Ministry of Education and Culture is currently based on official information, ready with all scenarios, including encouraging online learning for students [7].

The use of mobile technology can also be an alternative solution to the problem of limited equipment and laboratory-based learning resources that have existed so far. The use of technology in practicum activities also has the potential to help students in their learning activities. In addition, as a measurement instrument, mobile devices are able to integrate measurement sensors into an all-in-one, which allows for various measurements. Applications that contain 
mobile devices are intended to make measurements fairly quickly and precisely [8].

Simple experiments with even more complex experiments can be carried out with mobile devices (devices) to determine fundamental physical variables. Through sensors in the device, experiment-based learning becomes easier to do both in the classroom or at home and in recreational parks [9]. Research results from Cziprok, Miron, and Popescu (2014) also show that students who carry out experimental activities integrated with cellphones and computers experience increased learning motivation [10].

\section{METHOD}

Systematic literature review (SLR) provides answers to certain research questions [11]. The stages in a systematic literature review are shown in Figure 1. Before the research, we will discuss how the steps are carried out in each SLR phase.

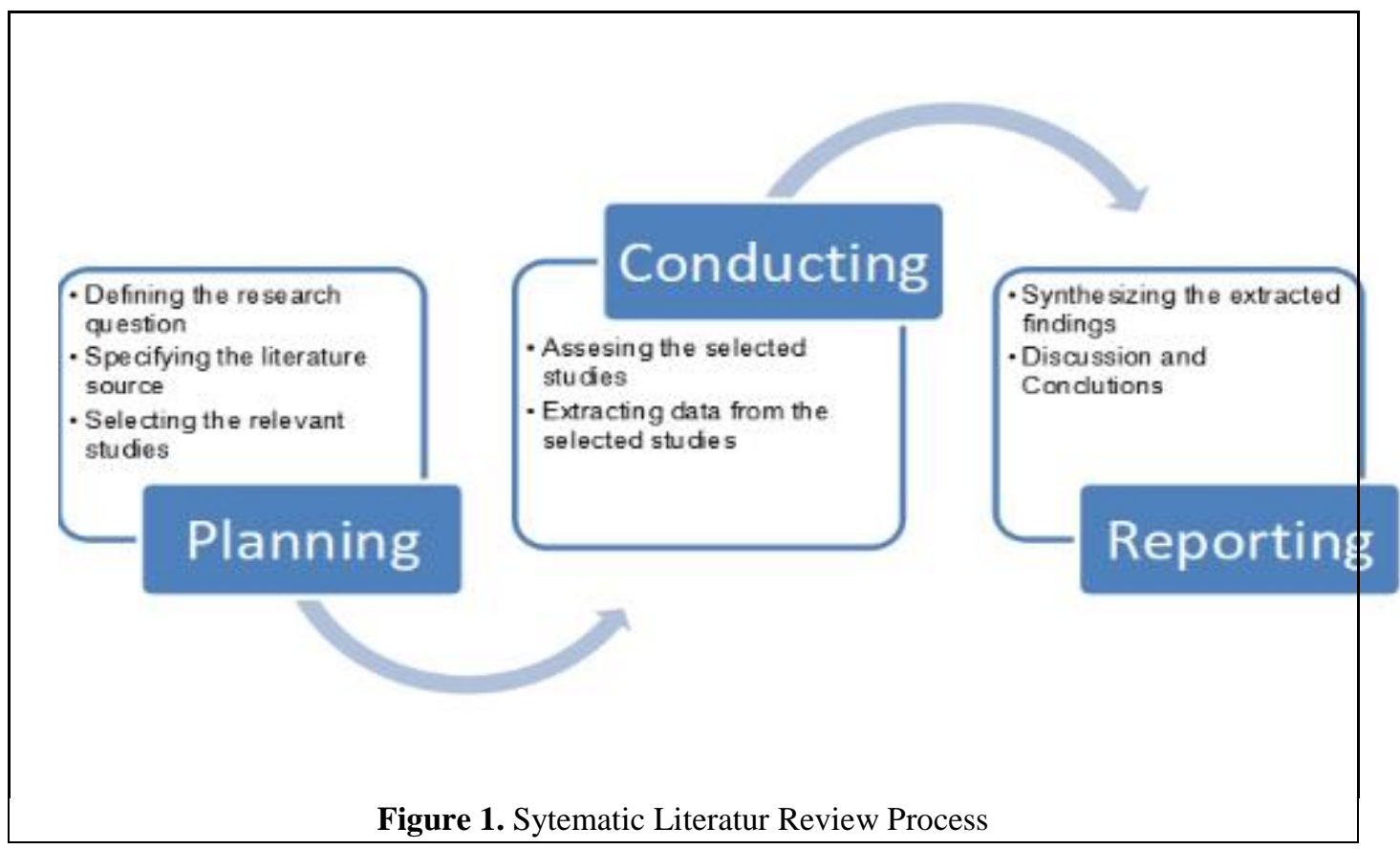

\subsection{SLR Planning}

Need to collect the best evidence from the existing literature. The SLR process provides the best techniques for gathering and analyzing evidence from primary literature review / studies. This section also discusses the importance of various methods for each research question. The study was chosen based on the title, abstract, and conclusions. The search results in this section illustrate that no SLR has the same coverage.

It is important to get a general picture of how to carry out experimental activities related to physics learning amid the conditions of Covid-19 and restrictions on laboratory access. The questions and objectives of the study are presented in table 1 .

Sources of data in this study were obtained through searching through other websites, proquest, taylor and fracis and Google Scholar to search research databases. In the secondary search, the primary search was evaluated by title, abstract, and conclusion, and finally, it was approved by searching the bibliography of the work to answer the research questions and objectives.

\subsection{SLR Implementations}

In this section all the articles collected are analyzed and extracted and then selected according to existing research questions. To answer research questions, we set a set of selection criteria.

The first part is that research must focus on experimental activities that are likely to be carried out independently and able to be integrated with distance learning. Published research that did not address these factors was excluded.

The second part, the research must be empirical, reporting data generated from actual observations or experiments. Articles based on personal opinion or anecdotal experience are excluded. The theoretical and conceptual parts are also excluded from the analysis but are carefully reviewed to strengthen our background knowledge and to broaden the theoretical foundation.

The third part, the research must be published in a peer-reviewed academic journal, in English, from 2008 to 2020 to review the latest studies and issues about the use of technology that supports experiment-based 
learning in distance learning. Papers published in nonpeer-reviewed, non-English-language journals, or outside this time frame are issued.

\subsection{SLR Report}

\section{RESULTS AND DISCUSSIONS}

Tabel 1. Research Questions and Objectives

\begin{tabular}{|l|l|l|}
\hline & \multicolumn{1}{|c|}{ Research Questions } & \multicolumn{1}{c|}{ Research Objectives } \\
\hline 1 & $\begin{array}{l}\text { Any platform that can be an } \\
\text { alternative means of } \\
\text { experiment based learning in } \\
\text { the era of distance learning. }\end{array}$ & $\begin{array}{l}\text { Knowing platforms that can be used in experimental } \\
\text { activities during the Covid -19 pandemic }\end{array}$ \\
\hline 2 & $\begin{array}{l}\text { Strengths and weaknesses of } \\
\text { each platform }\end{array}$ & $\begin{array}{l}\text { Knowing the advantages and disadvantages of each } \\
\text { learning technology platform that can be used as a means } \\
\text { of experimentation. }\end{array}$ \\
\hline 3 & $\begin{array}{l}\text { The influence of each platform } \\
\text { in learning activities }\end{array}$ & $\begin{array}{l}\text { Knowing the effectiveness of using each platform in } \\
\text { achieving learning objectives. }\end{array}$ \\
\hline
\end{tabular}

\subsection{Results}

The use of online learning in the pandemic era due to covid-19 became very important. The use of network media in general has also been proven to be able to improve students' academic achievement [12]. Virtual Laboratory Activities is one of the implementations that can be an alternative in efforts to improve student learning outcomes [13]. The use of video is one of the most commonly used tools in learning technology in the future [14]. Other technologies, such as flip learning based on augmented reality or remote laboratory systems, have been shown to improve student performance as well as student motivation [15], [16]. The advantages of using the lab. virtual / simulation can be seen in table 2 .

Virtual/Simulation Lab.

The use of simulations is an effective tool for conceptual understanding; also, they help students to develop their understanding of concepts; However, there are many practical goals that the simulation is unable to achieve, for example, specific skills related to the use of practical tools [3], [17]. Virtual / Simulation Lab also has the disadvantage of being difficult to accommodate group-based and psychomotor learning activities [17].

Vid Lab.

Mobile devices such as smartphones and tablets are equipped with sensors that can be read without time delay by specially developed applications. In this way, data can be measured digitally and visualized in various forms of representation, such as tables and graphs, automatically and in real-time. The basis of this non-
This section discusses the answers to each of the research questions, and the assessment or answers to the questions raised are based on an analysis of the selected article. Facts from each research question were extracted after analysis of the selected study.

contact measurement method is the video recording of a moving object, from which speed and acceleration can be calculated [18]. 


\section{Remote Lab}

The results showed that the use of virtual measuring instruments had the same effect as the use of physical measuring devices in terms of increasing students' understanding of physics concepts [13].

Shortcomings and negative comments related to the technical use of remote labs include the awkward operation of remote experiments. Besides that, the device/interface is difficult to control, as well as the lack of experience of experimental activities compared to manual laboratory activities [16].

remote laboratories are proven to produce higher cognitive and affective outcomes than practical laboratories. Remote lab-based learning has also proven to be more efficient [26]. The advantages of using a remote lab. can be seen in table 2 .

The weakness of the remote lab. Awkwardness from teachers and students for the existing operating system [16]. Difficulty controlling remote-operated devices [16], [23]. The remote lab has a weakness that is difficult to accommodate the psychomotor abilities of students [17]. An unstable Internet connection causes work failure / malfunction [27], [28].

\subsection{Discussion}

Learning during the Covid-19 pandemic changed the pattern of education from face-to-face to online learning. Although this situation is in line with the vision and mission of future learning in the era of the industrial revolution 4.0 and community 5.0, it still has advantages and disadvantages [7].

Laboratory activities have a positive impact on improving scientific skills, such as, formulating goals, conducting experiments, applying laboratory tools, and collecting data [43].
The use of virtual labs, video analysis labs, remote labs became an important part of experimental activities in learning physics, especially in the pandemic era Covid -19. The use of video lab analysis has the potential to be used in distance learning to accommodate laboratory-related physics courses [44].

Both the use of technology in experiments and LMS can reduce the weaknesses of each platform. The integration of experimental activities and LMS is needed to help students gain knowledge through practical sessions [45]. The virtual learning environment, which is obtained by using virtual and remote laboratories, must mimic both students and teachers if we want to realize the goals of the educational process in this way successfully. This learning environment must be based on constructivism learning theory and the abortion collections of all individuals involved in the course. Learning Management Systems (LMS) provide these requirements and are widely used in education [46].

Through video analysis of real experiments, students gain real experience of doing experiments, analyzing graphs, and finding equations of motion like a scientist. Learning is easier and more fun for students. It is recommended to identify students' misconceptions about the concept of movement and carry out remediation using real experimental video analysis. The introduction of distance laboratories gives students the opportunity to conduct independent research and thus have their own unique learning experiences. The experience of remote experiments can also be conveyed to students by integrating the technical and didactic laboratory into the LMS [47]. The implementation of the remote lab which is integrated with LMS is proven to be able to encourage independent learning and increase students' learning motivation [48].

Table 2. Technological superiority in experiments in the pandemic era

\begin{tabular}{|c|c|c|c|}
\hline \multirow{2}{*}{ factor } & \multicolumn{3}{|c|}{ Attainment } \\
\hline & Virtual/ Simulasi Lab. & Vid. Lab. & Remote Lab \\
\hline $\begin{array}{l}\text { Conceptual } \\
\text { Understanding }\end{array}$ & $\begin{array}{l}\text { The use of computer } \\
\text { simulations is proven to be able } \\
\text { to increase students' knowledge } \\
\text { and understanding of concepts } \\
\text { [29], [30], [31], [32]. }\end{array}$ & $\begin{array}{l}\text { learners are able to link the } \\
\text { concepts of physics with real } \\
\text { life [33] and are able to } \\
\text { improve understanding of } \\
\text { physics concepts [34]. }\end{array}$ & $\begin{array}{l}\text { Results The use of remote } \\
\text { labs shows an increase in } \\
\text { understanding of concepts for } \\
\text { students [26] }\end{array}$ \\
\hline Creativity & $\begin{array}{l}\text { Increase students' creativity } \\
\text { [35] }\end{array}$ & $\begin{array}{l}\text { Video analysis in learning } \\
\text { physics can improve creative } \\
\text { thinking [36]. }\end{array}$ & $\begin{array}{l}\text { The use of remote lab can } \\
\text { encourage students' creativity } \\
{[37] \text {. }}\end{array}$ \\
\hline Motivation & $\begin{array}{l}\text { Able to increase students' } \\
\text { motivation to learn physics [38]. }\end{array}$ & $\begin{array}{l}\text { The use of video tracking in } \\
\text { the activities of stronger } \\
\text { motivational experiments and } \\
\text { a good learning atmosphere } \\
\text { in the classroom [39]. }\end{array}$ & $\begin{array}{l}\text { The effects of Remote } \\
\text { Laboratory include improving } \\
\text { learning conditions, } \\
\text { increasing student motivation } \\
\text { [13], [26], [28]. }\end{array}$ \\
\hline Ability and skills & $\begin{array}{l}\text { Able to develop questions and } \\
\text { thinking skills [40] even to } \\
\text { higher order thinking skills [41]. }\end{array}$ & $\begin{array}{l}\text { Video analysis in learning } \\
\text { physics can improve creative } \\
\text { thinking skills, analytical } \\
\text { skills, and problem solving } \\
\text { skills [36]. }\end{array}$ & $\begin{array}{l}\text { The use of remote lab. Can } \\
\text { develop students' skills [42] }\end{array}$ \\
\hline
\end{tabular}




\section{CONCLUSION}

The COVID-19 pandemic has changed many habits and activities, including in education. Physics education with physics learning in it also feels this impact. As a science that requires experimental activities, learning physics also requires a breakthrough in experimental / laboratory activities that can be carried out outside the classical laboratory space. The use of virtual/ lab simulations, video labs, and remote labs has many advantages that can strengthen and replace experimental activities in the lab. conventional. The integration of existing technologies both in virtual / simulation, video lab, and also remote lab into LMS can be an alternative implementation of physics learning in the pandemic era due to COVID-19.

\section{ACKNOWLEDGMENTS}

Appreciation and gratitude to the Directorate of Research and Community Service, Deputy for Strengthening Research and Development, Ministry of Research and Technology/National Research and Innovation Agency for doctoral dissertation research (PDD), research activities in accordance with the 2020 Budget Research with Contract Number: 058 / SP2H / LT / DRPM / 2020. Thank you also to Yogyakarta State University for helping with this research activity.

\section{REFERENCES}

[1] Shahali EH, Halim L, Treagust DF, Won M, Chandrasegaran AL. 2017. "Primary school teachers' understanding of science process skills in relation to their teaching qualifications and teaching experience." Res Sci Educ., 47.2 (2017): 257-281. https://doi.org/10.1007/s11165-015-9500$\mathrm{Z}$

[2] Darmaji D, Kurniawan DA, Parasdila H, Irdianti I. 2018. Deskripsi keterampilan proses sains mahasiswa pada materi termodinamika. Berkala Ilmiah Pendidikan Fisika. 31;6(3):345-53. https://doi.org/10.20527/bipf.v6i3.5290

[3] Hockicko P, Krišt' ák LU, Němec M. "Development of students' conceptual thinking by means of video analysis and interactive simulations at technical universities." European J Engineering Educ 40.2 (2015):

145-166. https://doi.org/10.1080/03043797.2014.941337

[4] Musik P. Development of Computer-Based Experiment Set on Simple Harmonic Motion of Mass on Springs. Turkish Online J Educ TechnolTOJET. 2017 Oct;16(4):1-1.
[5] Thomas GP, Meldrum A, Beamish J. 2017 "Transforming the Learning Environment of Undergraduate Physics Laboratories to Enhance Physics Inquiry Processes". Scientia in educatione. 25;8. https://doi.org/10.14712/18047106.754

[6] Crawford J, Butler-Henderson K, Rudolph J, Glowatz M. COVID-19: 20 'Countries' Higher Education Intra-Period Digital Pedagogy Responses". J Applied Teach Learn (JALT). 2020 Apr 1;3(1). https://doi.org/10.37074/jalt.2020.3.1.7

[7] Abidah A, Hidaayatullaah HN, Simamora RM, Fehabutar D, Mutakinati L. "The Impact of Covid19 to Indonesian Education and Its Relation to the Philosophy of Merdeka Belajar". Studies Phil Sci Educ. $2020 \quad$ Apr $1 ; 1(1): 38-49$. https://doi.org/10.46627/sipose.v1i1.9

[8] Oprea, M., 2017. The Use Of Smartphones In The Physics Class: Distance Measurements. In Conference proceedings of» eLearning and Software for Education «(eLSE) (Vol. 2, No. 01, pp. 128-135)." Carol I" National Defence University Publishing House.

[9] Kuhn J, Vogt P. "Smartphones as experimental tools: Different methods to determine the gravitational acceleration in classroom physics by using everyday devices". European J Phys Educ. 2013;4(1):16-27. https://doi.org/10.1523/JNEUROSCI.6303-11.2012

[10] Cziprok CD, Miron C, Popescu F. 2014. "InquiryBased Learning Using Mobile Physics LaboratoryIpad, Bluetooth And Sensors". eLearn Software Educ. 2014 Apr 1(2).

[11] Hussain N, Turab Mirza H, Rasool G, Hussain I, Kaleem M. 2019. "Spam review detection techniques: A systematic literature review". Appl Sci. 9(5):987.

[12] Badia, A., Martín, D. and Gómez, M., 2019. "Teachers' perceptions of the use of Moodle activities and their learning impact in secondary education". Tech Know Learn. 24(3), pp.483-499. https://doi.org/10.1007/s10758-018-9354-3 .

[13] Zacharia ZC, Olympiou G. 2011. "Physical versus virtual manipulative experimentation in physics learning". Learning and instruction. 21(3):317-31. https://doi.org/10.1016/j.learninstruc.2010.03.001 .

[14] Pierce, R. and Fox, J., 2012.” Vodcasts and activelearning exercises in a 'flipped classroom' model of a renal pharmacotherapy module". American $j$ pharmaceutical educ, 76(10). https://doi.org/10.5688/ajpe7610196 . 
[15] Chang, S.C. and Hwang, G.J., 2018. "Impacts of an augmented reality-based flipped learning guiding approach on students' scientific project performance and perceptions". Computers \& Education, $\quad 125, \quad$ pp.226-239. https://doi.org/10.1016/j.compedu.2018.06.007 .

[16] Tho, S.W. and Yeung, Y.Y., 2016. "Technologyenhanced science learning through remote laboratory: System design and pilot implementation in tertiary education". Australasian J. Educ. Technol, 32(3). https://doi.org/10.14742/ajet.2203 .

[17] Chen, S., Lo, H.C., Lin, J.W., Liang, J.C., Chang, H.Y., Hwang, F.K., Chiou, G.L., Wu, Y.T., Lee, S.W.Y., Wu, H.K. and Wang, C.Y., 2012. "Development and implications of technology in reform-based physics laboratories". Phys. Rev. ST. Phys Educ Res, 8(2), p.020113. https://doi.org/10.1103/PhysRevSTPER.8.020113 .

[18] Becker S, Klein P, Gößling A, Kuhn J. 2020. "Using mobile devices to enhance inquiry-based learning processes". Learning Instruction. 69:101350.

https://doi.org/10.1016/j.learninstruc.2020.101350 .

[19] Anissofira, A., Latief, F.D.E., Kholida, L. and Sinaga, P. 2017. "Newton's cradle experiment using video tracking analysis with multiple representation approach". J. Phys.: Conf. Ser. (Vol. 895). https://doi.org/10.1088/17426596/895/1/012107.

[20] Yusuf E. "Using Tracker to Engage Students' Learning and Research in Physics." Pertanika J. Sci \& Technol. 24, no. 2 (2016): 483-491.

[21] Susilawati S, Satriawan M, Rizal R, Sutarno S. 2020. "Fluid experiment design using video tracker and ultrasonic sensor devices to improve understanding of viscosity concept". J. Phys.: Conf. Ser. Vol. 1521, p. 022039. https://doi.org/10.1088/1742-6596/1521/2/022039 .

[22] Aguilar-Marín P, Chavez-Bacilio M, JáureguiRosas S. 2018. "Using analog instruments in Tracker video-based experiments to understand the phenomena of electricity and magnetism in physics education". European J. Phys. 2018 Mar 27;39(3):035204. https://doi.org/10.1088/13616404/aaa8f8 .

[23] Onorato P, Mascheretti P, DeAmbrosis A. 2013. "Studying motion along cycloidal paths by means of digital video analysis". European J. Phys. 2013 May 2;34(4):921. https://doi.org/10.1088/01430807/34/4/921.
[24] De Jesus VL, Sasaki DG. 2018. "A Simple Experiment to Determine the Moments of Inertia of the Fidget Spinner by Video Analysis". The Physics Teacher. 56(9):639-42. https://doi.org/10.1119/1.5080587

[25] Dewanto, A., Lim, G.Q., Kuang, J., Zhang, J. and Yeo, Y., 2012. The world in slow motion: Using a high-speed camera in a physics workshop. Physics Education, 47(6), p.764. https://doi.org/10.1088/0031-9120/47/6/764 .

[26] Post, L.S., Guo, P., Saab, N. and Admiraal, W., 2019. "Effects of remote labs on cognitive, behavioral, and affective learning outcomes in higher education". Computers \& Education, 140, p.103596.

[27] Grodotzki, J., Ortelt, T.R. and Tekkaya, A.E., 2018. "Remote and virtual labs for engineering education 4.0: achievements of the ELLI project at the TU Dortmund University". Procedia Manufacturing, 26 , pp.1349-1360. https://doi.org/10.1016/j.promfg.2018.07.126

[28] Aththibby, A., Lubis, S. and Ardiyanti, Y. 2019. "Tpack as Innovation of Learning Science Laboratory of Indonesia". In 6th International Conference on Educational Research and Innovation (ICERI 2018). Atlantis Press. https://doi.org/10.2991/iceri-18.2019.27

[29] Foti, S., and Ring, G. 2008. "Using a simulationbased learning environment to enhance learning and instruction in a middle school science classroom". Journal of Computers in Mathematics and Science Teaching, 27(1), 103-120

[30] Sarabando C, Cravino JP, Soares AA. 2014. "Contribution of a computer simulation to students' learning of the physics concepts of weight and mass". Procedia Technology. 13:11221. https://doi.org/10.1016/j.protcy.2014.02.015 .

[31] Theyßen H, Struzyna S, Mylott E, Widenhorn R. 2016. Online physics lab exercises-A binational study on the transfer of teaching resources. Int J of Sci and Math Educ . 14, 865-883. https://doi.org/10.1007/s10763-014-9613-2

[32] Manunure K, Delserieys A, Castéra J. 2019. The effects of combining simulations and laboratory experiments on Zimbabwean students' conceptual understanding of electric circuits. Research in Science \& Technological Education. 1-9. https://doi.org/10.1080/02635143.2019.1629407

[33] Wee LK, Chew C, Goh GH, Tan S, Lee TL. 2012. Using Tracker as a pedagogical tool for understanding projectile motion. Phys. Educ. 
47(4):448. $\quad$ https://doi.org/10.1088/0031$9120 / 47 / 4 / 448$

[34] Hockicko, P., 2012. Attractiveness of learning physics by Means of Video Analysis and Modeling Tools. Physics and Engineering, 23, p.26.

[35] Astutik S, Prahani BK. 2018. The Practicality and Effectiveness of Collaborative Creativity Learning (CCL) Model by Using PhET Simulation to Increase Students' Scientific Creativity. International Journal of Instruction. 11(4):409-24.

[36] Firdaus T, Setiawan W, Hamidah I. 2017. The Kinematic Learning Model using Video and Interfaces Analysis. J. Phys.: Conf. Ser. 895 012108 . https://doi.org/10.1088/1742$6596 / 895 / 1 / 012108$

[37] Terkowsky, C. and Haertel, T., 2013, March. Where have all the inventors gone? Fostering creativity in Engineering Education with remote lab learning environments. In 2013 IEEE Global Engineering Education Conference (EDUCON) (pp. 345-351). IEEE.

[38] Rutten N, van der Veen JT, van Joolingen WR. 2015. Inquiry-based whole-class teaching with computer simulations in physics. International journal of science education. 37(8):1225-45. https://doi.org/10.1080/09500693.2015.1029033

[39] Hockicko, P., Trpišová, B. and Ondruš, J., 2014. Correcting students' misconceptions about automobile braking distances and video analysis using interactive program tracker. Journal J Sci Educ Technol 23, 763-776 (2014). https://doi.org/10.1007/s10956-014-9510-z

[40] Sulisworo D, Handayani T, Kusumaningtyas DA. 2019. The critical thinking effect of the computer simulation in the physics teaching and learning. . $J$. Phys.: $\quad$ Conf. Ser.1157 032003. https://doi.org/10.1088/1742-6596/1157/3/032003

[41] Yusuf I, Widyaningsih SW. 2019. HOTS profile of physics education students in STEM-based classes using PhET media. J. Phys.: Conf. Ser.1157 032021 . . https://doi.org/10.1088/1742$6596 / 1157 / 3 / 032021$

[42] Viegas, C., Pavani, A., Lima, N., Marques, A., Pozzo, I., Dobboletta, E., Atencia, V., Barreto, D., Calliari, F., Fidalgo, A. and Lima, D., 2018. Impact of a remote lab on teaching practices and student learning. Computers \& Education, 126, pp.201216. https://doi.org/10.1016/j.compedu.2018.07.012

[43] Iradat, R.D. and Alatas, F., 2017. The implementation of problem-solving based laboratory activities to teach the concept of simple harmonic motion in senior high school. J. Phys.: Conf. Ser.895 012014 . IOP Publishing. https://doi.org/10.1088/1742-6596/895/1/012014

[44] Pratidhina, E., Dwandaru, W.S.B. and Kuswanto, H., 2020. Exploring Fraunhofer diffraction through Tracker and spreadsheet: An alternative lab activity for distance learning. Revista Mexicana de Física E, pp.285-290. https://doi.org/10.31349/RevMexFisE.17.285

[45] Al-Khanjari, Z. and Al-Roshdi, Y. 2015. Developing virtual lab to support the Computer Science Education in Moodle. In Proceedings of 2015 12th International Conference on Remote Engineering and Virtual Instrumentation (REV) (pp. 186-191). IEEE.

[46] Popović, N. and Naumović, M.B., 2016. "Virtual laboratory and learning management system in optimal control theory education". International Journal of Electrical Engineering Education, 53(4), pp.357-370.

https://doi.org/10.1177/0020720916639321

[47] Terkowsky, C., May, D., Haertel, T. and Pleul, C., 2016. Integrating Remote Labs into Personal Learning Environments-Experiential Learning with Tele-Operated Experiments and E-Portfolios. Engineering Education 4.0 (pp. 213-228). https://doi.org/10.1007/978-3-319-46916-4_17.

[48] Franuszkiewicz, J., Heix, S., Frye, S., Haertel, T. and Terkowsky, C. 2019. From laboratory education to laboratory edu-action: evaluation of a redesigned lab course for prospective technology teachers and resulting demands for cyber-physical 'remotification'. In 2019 5th Experiment International Conference (exp. at'19) (pp. 128132). IEEE. 